\title{
Involvement in Curriculum Change
}

\author{
Catherine E. Pasterczyk
}

\begin{abstract}
Many sources of information exist for selectors and bibliographers in academic libraries to learn about curriculum change. A survey of the heads of collection development in 104 ARL libraries was conducted to determine the usefulness of these sources and the extent of library involvement in planning for curriculum change. Some factors having an influence on this involvement, such as library representation on curriculum committees and informal contacts with faculty, are examined in detail. The role of the General Library in the establishment of new courses and programs at the University of New Mexico is discussed, as are methods used at other universities.
\end{abstract}

he mission of a university library to support the teaching, research, and service goals of its parent institution is largely fulfilled through the selection of appropriate library materials. A collection development policy statement (where one exists) serves as an exceedingly useful guide to what the collections are and what they should be. This document, partly because of its mode of production, is always somewhat out-of-date. Selectors must have a means of keeping up with changes in the university that should be reflected in the collections. This study of Association for Research Libraries (ARL) members represents a beginning effort to quantify the extent and nature of ARL selector involvement in planning for curriculum change and to identify methods effective in this process.

The library's responsibility to support the university's teaching functions through appropriate selection of materials is an old and enduring idea. ${ }^{1,2,3,4}$ The "Standards for University Libraries" document clearly states, "A university library's collections shall be of sufficient size and scope to support the university's total instructional needs and to facilitate the university's research programs. ${ }^{\prime 5}$ Quantitative studies to determine if this is actually occurring are rare. ${ }^{6,7}$

Sources of information mentioned in the literature as being useful for librarians learning about the curriculum include the course catalog, faculty contacts, course syllabi, and the card catalog. The relative usefulness of these and other methods and the extent to which they are used are not discussed. Many authors ${ }^{8,9,10}$ emphasize informal means for learning of such change. David Kaser mentions that "significant inputs to the library plan are gleaned, almost through an underground intelligence network, from such circumstantial sources as hearsay, as things said rather than unsaid." "11 Edward Holley

Catherine E. Pasterczyk is science collection development coordinator, General Library, University of New Mexico, Albuquerque, New Mexico 87131. This article is based on a paper presented to the RTSD/RS Chief Collection Development Officers of Medium-Sized Research Libraries Discussion Group at the ALA Midwinter Meeting, Washington, D.C., January 5, 1985.

This research was supported by a grant from the Research Allocations Committee, University of New Mexico. The author would like to thank all the respondents to this survey and two anonymous reviewers for their comments. 
freely acknowledges, "despite his protestations that the librarian should be a valued member of every curriculum committee and informed of every move into a new research area . . . he will probably be one of the last to learn of these new developments unless he has informal contacts among the faculty., ${ }^{12}$ Numerous authors emphasize the need for learning of proposed changes and then planning support for the projected curriculum. ${ }^{13,14,15,16,15}$

This study seeks to address the following questions: (1) What sources of information are available to selectors/bibliographers for learning of existing and proposed curriculum? (2) How useful is each of these sources? (3) To what extent are librarians learning of proposed curriculum changes before they are implemented? (4) What are the characteristics of techniques used by librarians who always have prior knowledge of proposed curriculum change?

\section{METHODOLOGY}

A survey was mailed to the heads of collection development in ARL's 104 member libraries in the United States and Canada. The results reported here (see appendix A) are based on a 77 percent response rate. The data were analyzed using SPSS-X Release 2.0 as implemented on an IBM 3081D. Frequencies and crosstabulations including chi-square were run on certain variables. In cases where there was a high number of responses in an unanticipated category, such as "academic status" rather than a clear-cut "yes" or "no" for faculty status, another category was formed so as not to create an unintentional bias in the interpretation of the results. Data analyses were performed by both using and not using the other categories. Even though the data were analyzed quantitatively, they should probably be examined qualitatively: the sample size was small, and there was a possibility for varying interpretations of the questions.

\section{RESULTS AND DISCUSSION}

Despite the fact that liaison with academic departments is widely viewed as a top priority in collection development activities ${ }^{18}$ and that a myriad of methods for learning of curriculum changes are poten- tially available, ${ }^{19,20} 60.5$ percent of the respondents indicated that selectors/bibliographers "rarely" or "sometimes" have knowledge of proposed course changes in their areas of responsibility before they are implemented. Only 7.9 percent "always" had that knowledge, and 31.6 percent "often" did. This implies that, despite the clear and budgetarily significant link between curriculum and library materials acquisitions, few libraries are involved to any significant degree in curriculum planning.

One potential method for learning of curriculum change is through the faculty committee responsible for reviewing it. Approximately one-third ( 34.6 percent) of the respondents indicated that the library had a representative on the committee or otherwise knew what transpired at meetings by having an observer there or by receiving the minutes or the agenda. Onethird ( 34.6 percent) of respondents never had a representative on the committee; another third (31.9 percent) fell somewhere in between.

A summary of the other methods mentioned by respondents for learning of change is presented (tables 1 and 2). Not all the methods may be applicable to a particular situation, but it must be noted that the methods considered most useful are ones where direct communication between librarians and departmental faculty members occurs.

A positive, significant correlation was found between having an awareness of what transpires during curricula committee meetings and (1) having prior knowledge of curriculum change and (2) selectors being allowed an opportunity to comment on the change (see table 3 ). The curriculum committee or its equivalent was mentioned by a number of respondents as an appropriate, effective channel of communication. Seeking active involvement with this committee would be beneficial to many libraries.

The argument that faculty status in and of itself will improve selector awareness of curriculum change does not appear to be valid: 74.3 percent of respondents saw no change in selector awareness due to librarians having obtained faculty status. Only 20.0 percent felt that it contributed to 
TABLE 1

USEFULNESS OF SOURCES USED BY SELECTORS/BIBLIOGRAPHERS FOR LEARNING ABOUT COURSES/PROGRAMS

Sources of information

Informal contacts with individual facultyt Usefulness*

Meetings with department liaisons

Memberships on faculty curriculum committeest

Course catalogs

Attendance at departmental faculty meetings

Reserve booklists

Department-produced lists of classes

Course schedules

Attendance at general faculty meetings

Campus/faculty newspaper

Campus/student newspaper

Bookstore textbook lists

Departmental bulletin boards

*6 = most; 1 = least

tSignifies responses not specifically included on questionnaire but mentioned by $\mathrm{N}>=2$ respondents

Note: Other mentioned sources include membership on senate committees, lists of approved new courses, and employment interviews.

TABLE 2

\section{USEFULNESS OF SOURCES USED BY SELECTORS/BIBLIOGRAPHERS FOR} LEARNING ABOUT CHANGES IN COURSES/PROGRAMS

Sources of information Usefulness*

Informal contacts with individual facultyt

Memberships on faculty curriculum committeest

Meetings with department liaisons

Attendance at departmental faculty meetings

Lists of proposed course changes routed specifically to library

Course catalogs

Attendance at general faculty meetings

Reserve booklists

Course schedules

Department-produced lists of classes

Campus/faculty newspaper

Campus/student newspaper

Departmental bulletin boards

Bookstore textbook lists

*6 = most; 1 = least

tSignifies responses not specifically included on questionnaire but mentioned by $N>=2$ respondents

Note: Other sources mentioned include membership on senate committees, selector survey used for budget allocation, and information about new faculty appointments.

greater awareness, and 2.9 percent said it contributed to less awareness. One respondent remarked, "Faculty status does not assure bibliographer acceptance." In fact, no significant correlation was found between faculty status and whether (1) librarians are aware of curriculum change prior to the fact, (2) librarians have the opportunity to comment officially on how proposed curriculum changes will affect materials selected, or (3) libraries have an up-to-date collection development policy (see table 3). Apparently the methods for improving communication are more subtle than simply possessing faculty status.

One-half (49.3 percent) of the respondents indicated that selectors are not allowed to comment on how proposed course/program changes will affect materials selected. For the remaining half ( 50.7 percent), the opportunity to comment might occur only occasionally and applied only to program changes. Commentary was made through somewhat informal means or through various Faculty Senate committees. There is almost unanimous 
TABLE 3

CHI-SQUARE TEST: INDEPENDENCE OF SOME FACTORS POTENTIALLY ASSOCIATED WITH SELECTOR/BIBLIOGRAPHER AWARENESS OF CURRICULUM CHANGE

\begin{tabular}{lccccc}
\hline \hline & Update & Rep. & Fac. & Prior & Comment \\
\hline Current ${ }^{*}$ & $\alpha<.005$ & $\alpha<.100$ & NS & $\alpha<.050$ & NS \\
Update & & NS & NS & NS & NS \\
Rep. & & $\alpha<.100$ & $\alpha<.050$ & $\alpha<.100$ \\
Fac. Stat. & & & NS & NS \\
Prior & & & & $\alpha<.005$ \\
\hline
\end{tabular}

*Current = library has a current (revised within last five years) collection development policy.

Update = collection development policy is updated on a regular basis (at least every five years).

Rep. = library has representation on the university curriculum committee, i.e., committee

charged with discussing curriculum concerns such as degree requirements, course changes, etc.

Fac. stat. = librarians have faculty status.

Prior $=$ selector/bibliographers have knowledge of proposed course changes in their area(s) of responsibility before they are implemented.

Comment $=$ selectors are given an opportunity to officially comment on how proposed course/program changes will affect materials selected.

Figures given show the significance level at which the null hypothesis of independence can be rejected or, in other words, the probability of rejecting the null hypothesis of independence when the null hypothesis is true (Type I error). Statisticians often use $\alpha<.05$ as a cutoff point at which the alternative hypotheses of dependence can safely (i.e., with a probability $\alpha<.05 \%$ that a Type I error will occur) be accepted. Values $\alpha>.05$ are generally considered nonsignificant. The table shows values $\alpha>.100$ as being nonsignificant (NS).

agreement that both librarians and the university would benefit from librarians having this opportunity to comment, at least on major changes. There was a positive relationship between librarians having prior awareness of curriculum change and their being allowed to comment officially upon it. This may imply that once an official avenue for comment is put into effect it is easier for selectors to learn of changes, since automatic notification occurs, or that once selectors express an interest in curriculum change, they are more likely to be allowed to comment.

\section{ONE SOLUTION}

The procedure developed at the University of New Mexico (UNM) General Library for selector involvement in planning for curriculum change results from the belief that a combination of formal and informal communications between teaching faculty and library faculty is optimal.

Library faculty are voting members of the three standing committees of the Faculty Senate that are concerned with curriculum changes, the Curricula Committee, the Senate Graduate Committee, and the Undergraduate Committee. Additionally, the assistant dean for Collection Develop- ment is an ex officio member of the Curricula Committee. ${ }^{21}$

New course requests and major or minor curriculum change requests are first sent to the dean of Library Services for assessment of library impact. These requests are referred to the appropriate selector for comment, which provides selectors with an official notification that a new course is being proposed and the requesting department with an evaluation of anticipated library support. Often, the earlier, informal dialogue between librarians and teaching faculty is the first way librarians learn of new course proposals, and it is not unusual for consultation to take place during the selectors' evaluation. The new course requests are subsequently forwarded to the Curricula Committee, the college or school dean, and the Office of Graduate Studies. Faculty Senate minutes notify the selector of the requests' final disposition. It is possible, however, for a course to be offered as a special topic for several years without going through this process. Still, many respondents to the survey mentioned that they would like such a system; only six indicated that they have a comparable system in place.

The desirability of keeping the Library 
informed as plans are made for new programs was discussed by the Library Faculty Committee as early as the 1930 s. $^{22}$ The present communications system was achieved over a period of eight years and is based on a "concept of quality" for library service established partly through good selector/departmental liaison communications that helped build credibility and partly from the expectation of the library's high-quality response (within financial constraints) to the university's needs. The fact that university and state policies mandate an examination of the budgetary implications of a new course legitimized the impact statements prepared by library faculty. It was also argued that librarians, because they are faculty, should actively participate in planning the curriculum change rather than merely reacting to it. ${ }^{23}$

Some survey respondents commented that individual course changes should not affect library materials selection: a welldeveloped collection development policy would take care of such things, and library comment would only be valuable for major, i.e., program or degree changes. First, the achievement of library integration into the curriculum planning process at UNM was, of necessity, a gradual one. Library impact statements were first required for courses and then for programs and degrees. Second, the UNM General Library does not have a complete, up-to-date collection development policy and every little bit of information helps. Kaser noted "All librarians . . . serve as unique antennae, through which units of information can be received, some of great importance, some of small importance, but all of some importance. A well-run library will assure that all such information is fed, on a structured basis, into a central intelligence system where it can be noted, winnowed, evaluated against other input, and acted upon as appropriate on a continuing basis." ${ }^{24}$

\section{SOLUTIONS AT OTHER LIBRARIES}

These solutions are not unique to UNM: they are also used by the five other libraries where librarians "always" have knowledge of proposed course changes.
Many of these libraries are provided a space on university curriculum forms for selector comment on both graduate and undergraduate, new, modified, or deleted courses and programs. These forms sometimes include a bibliography of materials deemed important by the department. Course requests can be held up in committee for want of a library statement. Extensive resource evaluations are conducted by some selectors in the case of proposed degree programs. Several librarians mentioned that having the head of Collection Development or some other selector sit on the curriculum committee was very valuable. Where this is not feasible, receiving the minutes or agenda of the meetings is sometimes arranged. Membership on other senate committees is useful for some libraries. Besides being effective for those libraries that use them, the above solutions were frequently mentioned by other librarians as being desirable.

\section{CONCLUSIONS}

The problem of facilitating exchange between teaching faculty and librarians, particularly regarding curriculum change, is an old one, and the fundamental solution, informal face-to-face communication, is equally old. The present study confirms the benefits of this solution and shows that it is not used to its fullest potential. Selectors, the librarians with the most bibliographic knowledge of particular subject areas and influence on how collections are built, are rarely consulted automatically when curriculum changes are proposed.

A great deal has been written in the last few years about faculty status for librarians. Its attainment is viewed as a victory by librarians and with confusion by some teaching faculty. Faculty status by itself does not necessarily increase the efficacy of some collection development activities; faculty status does not affect how selectors maintain an awareness of what is happening within the university milieu. Rather, it is largely personal contacts with teaching faculty (not just departmental chairs or liaisons), graduate students, and departmental secretaries that is believed to be at the heart of effective communication. These informal contacts can provide the 
foundation for the development of formal channels of communication.

Selectors and bibliographers must therefore be given the opportunity to interact on an informal basis with faculty. They must be permitted to attend-at no charge and during work hours-classes, seminars, workshops, and field trips in the teaching departments. Attending faculty committee meetings should become a part of the selectors' normal workload. They should also be able to do online computer searches and library instruction in their areas of subject responsibility. Professional leave for attending subject- oriented professional meetings of groups such as Modern Language Association, Geological Society of America, and American Chemical Society-not just ALA and SLA-should be given freely. Educating the faculty about the library can be accomplished partly by hiring selectors with a knowledge of, or a genuine interest in, their selection areas. Librarians should be regarded as equals or partners in the overall educational process. With informal channels of communication firmly in place, the library, down to the selector level, can be formally and rightfully involved in planning for curriculum change.

\section{REFERENCES}

1. Mae L. Holt, "Collection Evaluation: A Managerial Tool," Collection Management 3:280 (Winter 1979).

2. John H. Whaley, Jr., "An Approach to Collection Analysis," Library Resources \& Technical Services 25:333 (July/Sept. 1981).

3. Mary B. Cassata and Gene L. Dewey, "The Evaluation of a University Library Collection: Some Guidelines," Library Resources \& Technical Services 13:452 (Fall 1969).

4. Edward J. Jennerich, "A Primer on Effective Library Utilization for Department Chairpersons," (Arlington, Va.: ERIC Document Preparation Service, 1978), p.3. (Microfiche ED 202 479).

5. "Standards for University Libraries," College \& Research Libraries News 4:102 (Apr. 1979).

6. Robert L. Burr, "Evaluating Library Collections: A Case Study," Journal of Academic Librarianship 5:256-60 (Nov. 1979).

7. Richard P. Palmer, "Integrating Library Acquisitions with the Curriculum," (Arlington, Va.: ERIC Document Reproduction Service, 1974). (Microfiche ED 140 804).

8. James O. Lehman, "Library-Faculty Liaison in the Small College," Southeastern Librarian 20:101-2 (Summer 1970).

9. Garold L. Cole, "The Subject Reference Librarian and the Academic Departments: A Cooperative Venture," Special Libraries 65:260 (July 1974).

10. Jerold A. Nelson, "Communication Between Reference Librarians and the Faculty in Selected California State Colleges"' (Ph.D. diss., Univ. of California-Berkeley, 1972), p.119.

11. David Kaser, "Planning in University Libraries; Context and Processes," Southeastern Librarian 21:212 (Winter 1971).

12. Edward G. Holley, "Effective Librarian-Faculty Relationships," Illinois Libraries 43:732-33 (Dec. 1961).

13. Manuel D. Lopez, "A Guide for Beginning Bibliographers," Library Resources \& Technical Services 13:465 (Fall 1969).

14. Marion L. Buzzard, "Writing a Collection Development Policy for an Academic Library," Collection Management 2:324 (Winter 1978).

15. Problems in University Library Management (Washington, D.C.: Association of Research Libraries, 1970), p.24, 43-44.

16. Robert M. O'Neil, "The University Administrator's View of the University Library," in Priorities for Academic Libraries, ed. Thomas J. Galvin and Beverly P. Lynch (San Francisco: Jossey-Bass, 1982), p.7.

17. William A. Moffett, "What the Academic Librarian Wants from Administrators and Faculty," in Priorities, p.19,21.

18. Diane C. Parker and Eric J. Carpenter, "A Zero-Base Budget Approach to Staff Justification for a Combined Reference and Collection Development Department," in New Horizons for Academic Libraries: Papers Presented at the First National Conference of the Association of College and Research Libraries, ed. Robert D. Stueart and Richard D. Johnson, (New York: K. G. Saur, 1979), p.477-78. 
19. General Libraries, University of Texas at Austin, Bibliographers Manual: Guide to the General Libraries Collection Development Program, (Austin, Tex.: University of Texas, 1982), p.14.

20. Mary B. Cassata and Gene L. Dewey, "The Evaluation," p.452.

21. Faculty Handbook (Albuquerque, N.M.: Univ. of New Mexico, 1983), p.A-14-A-23.

22. Univ. of New Mexico, "Minutes of the Library Committee. 1936-1966."

23. Paul Vassallo, personal communication, Nov. 1984.

24. Kaser, "Planning," p.212.

\section{APPENDIX A: SURVEY ON SOURCES OF INFORMATION FOR BIBLIOGRAPHER/SELECTOR AWARENESS OF CURRICULUM CHANGE}

Question 1: Does your library have a current (revised within the last five years) collection development policy?

$30(38.0 \%)$ Yes

$22(27.8 \%)$ No

$27(34.2 \%)$ Yes, for some parts of the collection

If yes, is it updated on a regular basis (at least every five years)?

$27(44.3 \%)$ Yes

$13(21.3 \%)$ No

$21(34.4 \%)$ Yes, for some parts of the collection

Question 2: Does the library have representation on the university curriculum committee, i.e., committee charged with discussing curriculum concerns such as degree requirements, course changes, etc.?

$23(29.5 \%)$ Yes, always

$13(16.7 \%)$ Occasionally

$6(7.7 \%)$ Seldom

$27(34.6 \%)$ Never

9 (11.5\%) Not applicable. Please explain:

Question 3: Do librarians at your institution have faculty status?

$39(49.4 \%)$ Yes

6 ( $7.6 \%)$ Academic Status

$34(43.0 \%)$ No

If yes, do you feel that there has been a change in bibliographer/selector awareness of course changes (additions/deletions/modifications) due to obtaining faculty status?

$7(20.6 \%)$ Yes, greater awareness

$1(2.9 \%)$ Yes, less awareness

$26(76.5 \%)$ No, no change due to faculty status

Question 4: Do bibliographers/selectors have knowledge of proposed course changes in their area(s) of responsibility before they are implemented?

$6(7.9 \%)$ Yes, always

$24(31.6 \%)$ Yes, often

$37(48.7 \%)$ Sometimes

$9(11.8 \%)$ Rarely

$0(0.0 \%)$ Never

Question 5: Are selectors at your institution allowed an opportunity to officially comment on how proposed course/program changes will affect materials selected?

$33(44.0 \%)$ Yes

$37(49.3 \%)$ No

5 ( $6.7 \%)$ Seldom

If yes, what form does this take? 
If no, do you think they would benefit from this opportunity?

$23(52.3 \%)$ Yes

$1(2.2 \%)$ No

$19(43.2 \%)$ Only for major program changes

1 ( $2.2 \%)$ Other. Please explain:

Also, if no, do you think the university would benefit from the librarians having this opportunity? $24(60.0 \%)$ Yes

$1(2.5 \%)$ No

$14(35.0 \%)$ Only for major program changes

$1(2.5 \%)$ Other. Please explain:

Question 6: Potentially how useful to the bibliographers/selectors are each of the following methods for learning about courses/programs offered at your university?

\begin{tabular}{|c|c|c|c|c|c|c|}
\hline \multirow{2}{*}{\multicolumn{2}{|c|}{ Most }} & \multicolumn{5}{|c|}{ Usefulness } \\
\hline & & - & & Lea & & Not applicable/ \\
\hline 6 & 5 & 4 & 3 & 2 & 1 & Not available \\
\hline 22 & 28 & 13 & 6 & 2 & 3 & 2 \\
\hline 10 & 15 & 14 & 13 & 10 & 12 & 2 \\
\hline 10 & 11 & 15 & 8 & 9 & 6 & 17 \\
\hline 1 & 3 & 15 & 10 & 18 & 19 & 9 \\
\hline 8 & 20 & 17 & 14 & 10 & 4 & 3 \\
\hline 1 & 2 & 5 & 15 & 19 & 25 & 8 \\
\hline 3 & 5 & 9 & 12 & 20 & 22 & 5 \\
\hline 3 & 9 & 8 & 16 & 11 & 12 & 14 \\
\hline 48 & 17 & 7 & 2 & 0 & 0 & 2 \\
\hline 4 & 14 & 6 & 6 & 17 & 10 & 16 \\
\hline 22 & 23 & 8 & 6 & 4 & 3 & 8 \\
\hline
\end{tabular}

\section{Course catalogs}

Course schedules

Department-produced lists of classes

Bookstore textbook lists

Reserve booklists

Departmental bulletin boards

Campus/student newspaper

Campus/faculty newspaper

Meeting with department liaison

Attendance at general faculty meetings

Attendance at departmental faculty meetings

Other

Question 7: What methods not currently available to your selectors would you like to see available for their use?

Question 8: Potentially how useful to the bibliographers/selectors are each of the following methods for learning about changes (additions/deletions/modifications) in courses/programs offered at your university?

Course catalogs

Course schedules

Department-produced lists of classes

Bookstore textbook lists

Reserve booklists

Departmental bulletin boards

Campus/student newspaper

\begin{tabular}{|c|c|c|c|c|c|c|}
\hline \multirow{2}{*}{\multicolumn{2}{|c|}{ Most }} & \multicolumn{5}{|c|}{ Usefulness } \\
\hline & & - & & Lea & & Not applicable/ \\
\hline 6 & 5 & 4 & 3 & 2 & 1 & Not available \\
\hline 12 & 20 & 9 & 8 & 11 & 11 & 3 \\
\hline 11 & 13 & 12 & 9 & 10 & 15 & 2 \\
\hline 9 & 9 & 11 & 10 & 9 & 13 & 13 \\
\hline 1 & 2 & 13 & 10 & 14 & 25 & 8 \\
\hline 8 & 18 & 9 & 13 & 11 & 12 & 2 \\
\hline 3 & 2 & 6 & 17 & 14 & 23 & 8 \\
\hline 3 & 9 & 6 & 11 & 14 & 25 & 6 \\
\hline
\end{tabular}


Campus/faculty newspaper

Meeting with department liaison

Attendance at general faculty meetings

Attendance at departmental faculty meetings

Lists of proposed course changes routed specifically to library

Other
Usefulness

\begin{tabular}{|c|c|c|c|c|}
\hline Most & \multicolumn{2}{|c|}{$\rightarrow$} & Least & \multirow{2}{*}{$\begin{array}{l}\text { Not applicable/ } \\
\text { Not available }\end{array}$} \\
\hline 65 & 4 & 3 & $\begin{array}{ll}2 & 1\end{array}$ & \\
\hline 310 & 8 & & 14 & 14 \\
\hline 16 & 72 & 4 & $\begin{array}{ll}0 & 1\end{array}$ & 2 \\
\hline 12 & 8 & $\begin{array}{ll}5 & 1\end{array}$ & 1 & 18 \\
\hline 22 & 6 & 4 & 3 & 10 \\
\hline 4 & 3 & 1 & 0 & 26 \\
\hline
\end{tabular}

Question 9: What methods not currently available to your selectors would you like to see available for their use in learning about changes?

Question 10: Your title:

Optional: To update my name/address file, could you also give the following.

Your name:

Address:

Feel free to comment on the topic of this questionnaire in the space below.

Please mail survey by November 15, 1984 to:

Catherine E. Pasterczyk

Science Reference/Collection Development Librarian

Zimmerman Library

The University of New Mexico

Albuquerque, NM 87131 USA

Thank you very much! 